ТЕОРІЯ ТА ІСТОРІЯ ДЕРЖАВИ І ПРАВА;

ІСТОРІЯ ПОЛІТИЧНИХ І ПРАВОВИХ УЧЕНЬ

УДК 316.334 .3 : 94](477) «192»

DOI https://doi.org/10.32844/2618-1258.2019.5-2.1

ДМИТРИК І.О., СУРЖЕНКО В.М.

\title{
ТЕОРЕТИЧНІ ЗАСАДИ СОЦІАЛЬНОЇ ПОЛІТИКИ УСРР В 1921-1928 РР.: МІСЦЕ РОБІТНИКІВ ТА СЕЛЯН У НОВОМУ КУРСІ
}

У статті на основі опублікованих та архівних джерел, наукової літератури розглянуто формування концептуальних засад соціальної стратегії держави в період НЕПУ щодо робітників та селян.

Після тривалого деструктивного періоду воєнних дій, економічної кризи та соціально-політичних експериментів нової влади на порядку денному керівництва держави стояли як поточні проблеми суспільного значення (порятунок безпритульних дітей, допомога безробітним, подолання житлової кризи, необхідність побудови системи охорони здоров'я), так і потреба визначити нові правила взаємодії влади та суспільства. Відповідно до класового підходу, який використовувався в цей період, становище різних верств населення не було тотожним. Виділялися соціальні групи, які внаслідок своєї лояльності до влади або з інших причин ставали пріоритетними адресатами пільг, соціального захисту, допомоги та ін.

Метою статті $є$ окреслення та порівняння місця робітників та селян у курсі соціальної політики УРСР 1921-1928 рр.

За умов обмеженості матеріальних ресурсів та вже створених рамок ідеології, якими були визначені категорії «свій»-«чужий», передбачалося витрачати державні ресурси та зусилля керівників всіх рівнів для надання матеріальної допомоги лише певним соціальним верствам, які становили соціальну базу партії.

Показово, що єдиними адресатами термінової державної допомоги на $\mathrm{X}$ з'їзді РКП(б) у березні 1921 р. були названі пролетарії та нужденні селяни; про труднощі інших суспільних груп - кустарів, службовців, інтелігенції та ін. офіційно не згадували.

Встановлено, що рішення партії та уряду в галузі соціальної політики в період НЕПу виокремлювали певні верстви суспільства, яким приділялася найбільша увага. Бачення партійним керівництвом місця та ролі окремих соціальних груп у структурі суспільства нової держави проявлялося, в першу чергу, в тих документах, якими регламентувалося матеріальне становище населення. Робітники традиційно користувалися підтримкою більшовиків, які постійно це декларували; селян поділяли на групи, вони вважали себе незаконно та несправедливо переведеними на другорядні ролі, а їхня ініціатива з включення до активного громадсько-політичного життя зустрічала недовіру та протидію з боку влади.

Ключові слова: сочіальна політика в 1921-1928 рр., розробка курсу, класовий підхід, матеріальна підтримка робітників, диференційоване ставлення влади до селян, обмеженість шкільної та медичної мережі в сільській місиевості.

(С ДМИТРИК І.О. - кандидат історичних наук, доцент кафедри історії та права (ДВНЗ «Донецький національний технічний університет»)

СУРЖЕНКО В.М. - старший викладач кафедри історії та права (ДВНЗ «Донецький національний технічний університет») 
The article focuses on the formation of conceptual foundations of the state social strategy in the NEP period in relation to workers and rural people on the basis of published and archival sources, and scientific literature.

After a long destructive period of hostilities, economic crisis and social and political experiments of the new government such current problems of public importance as saving homeless children, helping the unemployed, overcoming the housing crisis, the need to build a health care system, as well as the need to define new rules for the interaction between government and society were on the agenda for the state leadership. According to the class approach applied in this period, the state of different population segments was not identical. There were distinguished social groups which, due to their loyalty to the authorities or for other reasons, became the priority recipients of benefits, social protection, assistance, etc.

The purpose of the article is to describe and compare the place of workers and rural people in the course of social policy of the USSR in 1921-1928.

Given the scarcity of material resources and the established ideology frameworks, which defined the categories of "us" - "them", it was supposed to spend state resources and efforts of leaders of all levels to provide material assistance only to certain social groups which made up the social base of the party.

It is significant that proletarians and needy rural people were identified as the only recipients of urgent state aid at the 10th Congress of the RCPB in March, 1921; the difficulties of such social groups as artisans, employees, intellectuals and others were not officially mentioned.

It was found out that the decisions of the party and the government in the field of social policy during the NEP period paid more attention to certain sections of the society. The vision of the party leadership of the place and the role of individual social groups in the structure of the new state society was manifested, first of all, in the documents that regulated the financial position of the population. Workers were traditionally supported by the Bolsheviks, who always declared this; rural people were divided into groups; they considered themselves to be illegally and unfairly transferred to minor roles, and their initiative to engage in active social and political life was confronted by distrust and opposition from the authorities.

Key words: social policy in 1921-1928, course development, class approach, material support of workers, differentiated attitude of the authorities to the rural people, limited school and medical network in rural areas.

Вступ. Концептуальні основи соціальної політики в період НЕПу розроблялися, оформлювалися та транслювалися представниками органів влади та керівниками більшовицької партії. Розгляд та утвердження іiі основних положень відбувався на з'їздах та конференціях РКП(б) та КП(б)У у вигляді складових частин резолюцій, які являли собою певні директивні вказівки для місцевих партійних комітетів, профспілок, підприємств, керівників різних рівнів та всього населення. Крім того, правові засади соціальної політики містилися в постановах Всеукраїнського Центрального Виконавчого Комітету та Ради Народних Комісарів.

Процеси, що проходили в суспільно-політичному житті країни в 1920-х рр., були дуже складними та неоднозначними. Дедалі більше науковців у результаті осмислення фактів та подій історичного минулого періоду НЕПу доходять висновку, що стратегії внутрішнього реформування та розвитку держави, яка б крок за кроком програмувала реальні заходи, в більшовиків просто не було. Їх діяльність після відмови від політики «військового комунізму» була спровокована загрозою втратити владу. Мабуть, просто не існувало таких чарівних рецептів гармонійного поєднання революційної риторики та «небільшовицьких» економічних заходів, за якими вдалося б вивести країну з кризи, не втративши обличчя унікальної держави, якою керує диктатура пролетаріату.

Особливістю досліджень місця окремих верств суспільства в радянській соціальній політиці 1921-1928 рр. є підвищена увага до робітничої тематики, що зумовило появу значної кількості спеціалізованих та узагальнюючих праць. Водночас доробок радянської історіографії з цієї теми є найбільш заідеологізованим. Вивчення соціальної історії селянства періоду НЕПу в радянській історіографії представлено достатньо широко, проте з тими ж обмеженнями. Серед наукового доробку періоду незалежності слід назвати роботи О.М. Мовчан, П.В. Ямпольця, О.І. Ган- 
жи, В.М. Смирнова[1]. Соціальну політику на регіональному рівні Донбасу досліджувала одна 3 авторок цієї статті [2]. Серед праць узагальнюючого характеру необхідно зазначити колективні монографії «Нариси повсякденного життя Радянської України в добу НЕПу (1921-1928 рр.)» та «Суспільство і влада в радянській Україні років непу (1921-1928)» [3].

Проте розробка концепції соціальної взаємодії та підтримки робітників i/aбо селян у період НЕПу не дістала достатнього висвітлення, що й зумовило вибір теми запропонованої статті.

Постановка завдання. Метою статті є окреслення та порівняння місця робітників та селян у курсі соціальної політики УРСР 1921-1928 рр.

Результати дослідження. Насамперед владі треба було реагувати на жахливе економічне становище населення і країни загалом, зумовлене війнами, революцією та соціально-політичними експериментами. Іншими словами, перед більшовиками постало нагальне завдання порятунку громадян власної держави, але не від зовнішнього або політичного ворога, а від ворога внутрішнього - голоду, епідемій, загрози вимирання та демографічної катастрофи. Але за умов значної обмеженості матеріальних ресурсів та вже створених рамок ідеології, якими були визначені категорії «свій» - «чужий», рятувати збиралися далеко не кожного. У тому сенсі, що передбачалося витрачати державні запаси та зусилля керівників всіх рівнів для надання матеріальної допомоги лише певним соціальним верствам, які становили соціальну базу комуністичної партії; всі інші мали самі давати собі раду.

Яскравим прикладом цього є рішення Х з'їзду РКП(б), з якого почалося впровадження нової економічної політики. Він відбувся 8-16 березня 1921 р. і проголосив про перехід до нових форм управління народним господарством. Найбільш відомою постановою цього з'їду була постанова «Про заміну розкладки продподатком». Поряд із нею Х з’їздом 16 березня 1921 р. була прийнята постанова «Про поліпшення становища робітників і нужденних селян», в якій можна знайти перші задекларовані концептуальні засади нової соціальної стратегії.

Показовою є назва постанови, що декларує необхідність матеріальної підтримки будьяких робітників (оскільки стосовно цього іменника не вжито прикметник) та чітко визначеної групи селян - нужденних. Другим моментом, який демонструє диференційоване ставлення влади до цих верств суспільства, є диспропорція змістовного наповнення документа (робітникам присвячено чотири абзаци, нужденним селянам - лише один). Важливими є формулювання, якими обгрунтовувалося звернення до екстрених заходів. Так, становище робітників станом на $1921 \mathrm{p}$. характеризувалося як «виснаження від злиднів і бідувань, зв'язаних з семирічною війною та розоренням, і перевтома від майже надлюдського напруження сил» [4, с. 248]. Водночас нужденні селяни потребували допомоги «з огляду на значне лихо, заподіяне неврожаєм селянству і посилюване в дуже багатьох випадках демобілізацією армії» [4, с. 249]. За цими текстами виходить, нібито селяни взагалі не відчули на собі перипетій війн і революції, їх зачепив тільки голод (до речі, згаданий дуже стримано) та наслідки демобілізації. Мабуть, така подача минулого мала пояснювати, чому влада намагалася поліпшити становище не всіх селян.

Щодо конкретних заходів, спрямованих на виправлення ситуації та полегшення бідувань робітників «що б то не стало», пропонувалося «в найкоротший строк забезпечити, принаймні для робітників найважливіших центрів Республіки, такий пайок і такі умови життя, які дійсно були б для них стимулом лишатися на фабриках і заводах» [4, с. 248]. Для цього було заплановано провести натуралізацію заробітної плати, насамперед, у цих центрах. Крім того, з'їзд доручив ЦК створити спеціальну центральну комісію, пов'язану з ЦК РКП, ВЦРПС, РНК і РПО, яка, своєю чергою, мала створити підкомісії при тих відомствах, які мали частину їх апарату i кошти спрямувати на заходи поліпшення становища робітників (Наркомзовнішторг, Наркомпрод, Наркомвійськ, Наркомздоров'я та ін.), та підкомісії в губерніях найбільшого зосередження промислових робітників. Стосовно найбідніших селян з'їзд поклав на ЦК обов'язок провести через РНК і ВЦВК аналогічні заходи, незважаючи на те, що ВЦВК для цього вже була створена комісія.

Отже, єдиними адресатами термінової державної допомоги на Х з'їзді РКП(б) були названі пролетарії та нужденні селяни. Зауважимо, що про воєнні та повоєнні труднощі інших суспільних груп - кустарів, службовців та ін. в березні 1921 р. на рівні вищого партійного керівництва офіційно не згадували. Зрозумілим засобом цієї підтримки мала стати натуралізація заробітної платні (тобто видача іiі у вигляді продовольчих продуктів та речей широкого попиту), менш зрозумілим - створення та діяльність центральної, відомчих та губернських комісій.

На X з’ізді була прийнята ще одна постанова «Про роль і завдання профспілок», частина якої («Завдання в галузі нормування праці») уточнювала принципи тарифної політики. Проголошувалося, що цими питаннями мали опікуватися профспілки, але тут же партія давала їм 
протилежні накази: «повинна бути тимчасово збережена розбіжність в оплаті праці в залежності від кваліфікації», але «тарифна політика має будуватися на якомога більшому зрівнянні між ставками» [5, с. 166]. Суперечливими були положення про необхідність використовувати натуральну оплату праці як засіб дисциплінування і підвищення продуктивності праці, 3 одного боку, та завдання безплатного відпуску продуктів і предметів широкого вжитку для трудящих - 3 іншого.

У цій постанові, яка характеризує початковий період НЕПу, складно побачити чіткий курс у сфері регулювання оплати праці; поряд із бажаними правилами тут наведена констатація реальної ситуації.

Вже за кілька місяців центральним завданням у галузі розподілу стала відмова від зрівнялівки в оплаті праці. В 1921-1922 р. поряд із поступовим переходом на грошову систему оплати праці була впроваджена єдина 17-розрядна тарифна сітка для робітників та службовців. Вона встановлювала умови оплати праці для всіх категорій і професій співробітників підприємств та установ. Тарифна ставка 17 розряду у 8 разів перевищувала ставку першого, а тариф робітників вищої кваліфікації (9 розряд) був в 3,5 раза вище, ніж у робітників нижчої кваліфікації [6, с. 19].

Головною формою регулювання умов праці та виплати заробітної плати робітникам та службовцям у 1920-х рр. став колективний договір.

Можливості регламентації матеріального становища сільського населення в період НЕПу були обмеженими, оскільки політика заробітної плати впливала тут лише на найманих робітників, які становили меншість сільської громади (представників сільської інтелігенції та батраків). Селяни, що становили більшість населення країни, формували своє ставлення до радянської влади на основі інших критеріїв, які визначали їх рівень життя, - обсяг податків та співвідношення цін на продукти сільськогосподарського та промислового виробництва. Враховуючи, що обидва показники в 1920-х рр. не відповідали уявленням цієї верстви про соціальну справедливість, розгляд теоретичних засад соціальної політики, об'єктом якої були селяни, доречно побудувати не за принципом вивчення рішень парті та уряду, а на основі ознайомлення з вимогами мешканців села та реакцією на них керівників держави. Такий «зворотний» прийом дасть змогу усвідомити, які проблеми селяни вважали першочерговими і як вони вирішувалися владою.

Претензії та пропозиції цієї соціальної групи фіксувалися в політичних листах секретарів окружкомів, результатах обстежень настроїв населення та зберігаються в архівних фондах.

Головні прогалини соціальної політики радянської держави на селі, на думку селян, мали чіткий зв'язок із рівнем представництва у впливових владних та громадських структурах. Найголосніше про них заявляли на звітних зборах сільських рад перед перевиборами. Можна навести приклади гострих питань, які пролунали на таких заходах у Маріупольській окрузі в березні 1926 р. і які можна вважати типовими не тільки для селянства Донбасу, а й УРСР [7, арк. 4]:

1. Чому охоплення дітей школами неповне?

2. Чому медична допомога для селян абсолютно недостатня, а робітників не тільки лікуєте в госпіталях, але й посилаєте на курорти?

3. Чому на промтовари ціни високі, а на хліб - низькі?

4. Чому податок зменшили, а ціни підняли?

5. Кредити незаможникам!

6. Чому влада робітничо-селянська, а не селянсько-робітнича, адже робітники становлять меншість?

7. Дорого все тому, що робітники працюють 8 годин. Якщо б працювали 10 годин, то ціни були б набагато меншими (тут же наводять арифметичні викладки).

Отже, найбільше селян хвилювали питання диспропорції цін (а значить, нееквівалентного обміну між містом та селом, штучне зменшення рівня прибутків сільського населення), правило меншовартості верстви селян у радянській державі порівняно 3 верствою робітників, демонстративна лояльність влади до окремих груп селян (незаможників), а також обмеженість шкільної та медичної мережі в сільській місцевості.

Кульмінацією акумульованих нарікань та водночас способом їх контролю та задоволення стало перманентне декларування ідеї створення селянської професійної спілки. Аргументи на користь втілення цього задуму були зрозумілими кожному. Так, наприкінці 1926 р. у Маріупольській окрузі ця вимога була загальною для всіх районів і супроводжувалася такими висловлюваннями: «селян грабують, ніхто їх не захищає; у робітників є профспілки, вони живуть добре, їдуть на селянській шиї. Була б в нас селянська спілка, ми зуміли б відвоювати свої права» [7, арк. 40].

Висновки. Таким чином, рішення партії та уряду в галузі соціальної політики в 1921-1928 рр. виокремлювали певні верстви суспільства, яким приділялася найбільша увага. 
Бачення партійним керівництвом місця та ролі окремих соціальних груп у структурі суспільства нової держави проявлялося, насамперед, у тих документах, якими регламентувалося матеріальне становище населення. Робітники традиційно користувалися підтримкою більшовиків, які постійно це декларували; селян поділяли на групи, вони вважали себе незаконно та несправедливо переведеними на другорядні ролі, а їхня ініціатива з включення до активного громадсько-політичного життя зустрічала недовіру та протидію з боку влади.

Темою подальших розвідок може бути порівняння місця та ваги робітників і селян у концепції соціальної політики УРСР 1921-1928 pр. з призначенням та значенням інших верств населення (інтелігенції, кустарів, непманів, держслужбовців, партійних функціонерів тощо).

\section{Список використаних джерел:}

1. Мовчан О.М. Повсякденне життя робітників УСРР. 1920-ті pp. Київ : Інститут історії України НАН України, 2011. 312 с.; Ямполець П.В. Матеріальне становище робітників державної промисловості України в період НЕПу (історико-статистичний аналіз) : автореф. дис. ... канд. іст. наук : 07.00.01 / Нац пед. ун-т ім. М.П. Драгоманова. Київ, 2010. 20 с.; Ганжа О.І. Українське село в період становлення тоталітарного режиму (1917-1927 рр.). Київ, 2000. 208 с.; Смирнов B.M. Суспільно-політичні та економічні перетворення в українському селі в період нової економічної політики. Харків : Майдан, 2002. 304 с.

2. Дмитрик I.О. Соціальна політика радянської держави та ії реалізація в Донбасі в період НЕПу (1921-1928 рр.) : автореф. дис. ... канд. іст. наук : 07.00.01 / Донецький національний університет. Донецьк, 2010. 20 с.; Дмитрик I.О., Нікольський В.М. Соціальна політика радянської держави та її реалізація в Донбасі періоду НЕПУ (1921-1928 рр.). Донецьк : ДонНУ, 2011. 172 с.

3. Нариси повсякденного життя радянської України в добу непу (1921-1928рр.): колективна монографія : в 2 ч. /відп. ред. С.В. Кульчицький. Київ : Інститут історії України НАН України, 2009. Ч 1. 445 с.; Суспільство і влада в радянській Україні років непу (1921-1928): колективна монографія: в 2 т. / відп. ред. С. Кульчицький. Київ : Інститут історії України, 2015. Том 1. 656 с.

4. Про поліпшення становища робітників і нужденних селян. Комуністична партія Paдянського Союзу в резолюиіях і рішеннях з'їдів, конференцій і пленумів ЦК. 1898-1970 / За заг. ред. П.М. Федосєєва і К.У. Черненка. Київ : Політвидав України, 1979. Т. 2. 1917-1924. 521 с.

5. Резолюции Х съезда РКП(б) 15-16 марта 1921 г. Партия в борьбе за восстановление народного хозяйства (1921-1925 г2.). Документы и материалы. Москва : Госполитиздат, $1961.619 \mathrm{c}$.

6. Ставницкий А.В., Шехет И.Н. Невостребованный опыт (регулирование заработной платы в годы нэпа). Вестник Академии Наук СССР. 1991. № 2. С. 19.

7. Державний архів Донецької області. Ф. 11. Оп. 1. Спр. 119. 